\title{
The known unknowns of the human dendritic cell network
}

\author{
Mélanie Durand ${ }^{1,2}$ and Elodie Segura ${ }^{1,2}$ * \\ ${ }^{1}$ Centre de Recherche, Institut Curie, Paris, France \\ 2 INSERM U932, Paris, France
}

Edited by:

Florent Ginhoux, Singapore

Immunology Network, Singapore

\section{Reviewed by:}

Francesca Granucci, University of

Milano-Bicocca, Italy

Kristen J. Radford, University of

Queensland, Australia

*Correspondence:

Elodie Segura, INSERM U932, Institut

Curie, Pavillon Pasteur, 26 rue d'Ulm,

Paris Cedex 05 75248, France

e-mail: elodie.segura@curie.fr
Dendritic cells (DCs) initiate and orient immune responses and comprise several subsets that display distinct phenotypes and properties. Most of our knowledge of DC subsets biology is based on mouse studies. In the past few years, the alignment of the human DC network with the mouse DC network has been the focus of much attention. Although comparative phenotypic and transcriptomic analysis have shown a high level of homology between mouse and human DC subsets, significant differences in phenotype and function have also been evidenced. Here, we review recent advances in our understanding of the human DC network and discuss some remaining gaps and future challenges of the human DC field.

Keywords: human, dendritic cells, antigen presentation, DC subsets, ontogeny

\section{INTRODUCTION}

Dendritic cells (DCs) have long been known to be the most efficient antigen-presenting cells. It is now well established that DCs are a heterogeneous population composed of several subsets that can be distinguished by their phenotype, location, and functional properties (1). Due to their remarkable ability to stimulate $\mathrm{T}$ cells, DCs have become in the past decade attractive therapeutic targets. However, most of our knowledge of DC subsets biology was gained from mouse studies, and cross-species differences could hinder the successful translation to humans of major discoveries made in the mouse. In the past few years, a number of studies have tackled the analysis of human DC subsets. In this review, we summarize recent advances and highlight some of the outstanding questions that remain to be addressed.

\section{HOW TO DEFINE DC SUBSETS IN HUMANS?}

Historically, human DC subsets have been defined based on a small number of phenotypic markers, within the population of MHC class $\mathrm{II}^{+}$lineage-negative cells. In blood, DCs have been divided into two main groups: plasmacytoid DCs (pDC) and "myeloid" or "classical" DCs (cDCs). cDCs can be further separated into two subsets that are usually referred to as BDCA1/CD1c ${ }^{+}$DCs and $\mathrm{BDCA} 3 / \mathrm{CD} 141^{+} \mathrm{DCs}(2)$. These three DC populations are also found in all lymphoid organs and represent resident DCs (3-6). In skin, liver, lung, and intestine, two main populations of $\mathrm{CD}_{\mathrm{c}}{ }^{+} \mathrm{CD} 1 \mathrm{a}^{+} \mathrm{DCs}$ and $\mathrm{CD} 141^{+} \mathrm{Clec} 9 \mathrm{~A}^{+}$DCs have been identified (7-12). Tissue DCs can migrate through the lymph to the draining lymph nodes where these migratory DCs display a mature phenotype $(4,13,14)$. Additional DC subsets have been described in mucosal tissues: Langerhans cells (LCs) and CD14 ${ }^{+}$DCs (15, 16) in skin and vaginal mucosa, and $\mathrm{CD} 103^{-} \mathrm{CD} 172 \mathrm{a}^{+}$DCs in the intestine (10). Finally, a population of "inflammatory" DCs with a distinct phenotype can also be found in inflamed tissues $(17,18)$.

Although surface markers are useful for the characterization of DC subsets (Table 1), phenotypic analysis has proven insufficient on its own to define DC subsets. Indeed, some phenotypic markers are not specific of a given DC subset or their expression can change upon activation, potentially leading to misinterpretation. For instance, CD141 is upregulated upon activation on $\mathrm{pDC}$ and CD1c ${ }^{+}$DCs (19) and is also expressed by tissue CD14 ${ }^{+}$DCs (20). Clec9A, which is restricted to CD141 ${ }^{+} \mathrm{DCs}$, is downregulated rapidly during DC maturation (21). Another hurdle is the promiscuous expression of some markers on macrophages and monocytes, such as CD14 or CD64. Recently, CD14 ${ }^{+} \mathrm{CD} 1 \mathrm{c}^{\text {low }}$ cells in the skin were re-defined as macrophages (22). However, the identity of tissue $\mathrm{CD} 14^{+} \mathrm{CD} 1 c^{\text {high }}$ cells remains uncertain, we refer to these cells as CD14 ${ }^{+}$DCs throughout this review.

The analysis of key DC properties can help assessing the DC identity of a potential subset. Hallmark properties include dendritic morphology, migratory capacity, and ability to stimulate naive $\mathrm{T}$ cells. These properties have been used to distinguish macrophages from DCs in the skin $(22,23)$ and inflammatory fluids (17), or monocytes from DCs in the blood (24).

Finally, gene expression signatures have emerged from transcriptomic studies and can be a useful tool to confirm DC identity, to assign a population to a known DC subset, or to define a new one. Lineage-negative $\mathrm{CD}^{+} 6^{+}$blood cells were initially termed $\mathrm{CD} 6^{+}$DCs, but transcriptomic analysis showed that they are a subset of monocytes (25). Similarly, 6-sulfo LacNac/Slan ${ }^{+}$blood cells were termed Slan ${ }^{+}$DCs, but comparative transcriptomic analysis identified them as a subpopulation of $\mathrm{CD} 16^{+}$monocytes (24). Recently, dermal CD $14^{+} \mathrm{CD} 1 \mathrm{c}^{\text {low }}$ cells were found to be closer in their gene expression to macrophages than to DCs (22). Transcriptomic analysis has also been used to assess the proximity of tissue DC subsets with their blood counterparts for skin (8) or intestinal DCs (10).

\section{WHAT IS THE ONTOGENY OF HUMAN DC SUBSETS?}

Addressing human DC ontogeny is challenging, but in vitro culture models, clinical observations, and comparative transcriptomic analysis have provided substantial insight. Human DCs are constantly replenished from bone marrow precursors as shown by the replacement of dermal DCs after hematopoietic stem cell transplantation (23) and the loss of blood DCs after bone 
Table 1 | Phenotypic markers for human DC subsets

\begin{tabular}{|c|c|c|c|c|c|c|c|c|}
\hline Surface marker & pDC & $\begin{array}{l}\text { Blood/ } \\
\text { resident } \\
\text { CD1c DC }\end{array}$ & $\begin{array}{l}\text { Blood/ } \\
\text { resident } \\
\text { CD141 DC }\end{array}$ & $\begin{array}{l}\text { Tissue/migratory } \\
\text { CD1c CD1a DC }\end{array}$ & $\begin{array}{l}\text { Tissue/migratory } \\
\text { CD141 Clec9A DC }\end{array}$ & $\begin{array}{l}\text { Tissue/ } \\
\text { migratory } \\
\text { CD14 DC }\end{array}$ & $\begin{array}{l}\text { Inflammatory } \\
\text { DC }\end{array}$ & $\begin{array}{l}\text { Langerhans } \\
\text { cells }\end{array}$ \\
\hline HLA-DR & + & + & + & + & + & + & + & + \\
\hline CD11c & - & ++ & + & ++ & + & ++ & ++ & + \\
\hline CD123 & + & - & - & - & - & - & - & - \\
\hline BDCA2/CD303 & + & - & - & - & - & - & - & - \\
\hline BDCA4/CD304 & + & - & - & - & - & $?$ & $?$ & - \\
\hline Clec9A & - & - & $\begin{array}{l}+ \text { Immature } \\
\text { Low mature }\end{array}$ & - & + & - & - & - \\
\hline BDCA3/CD141 & $\begin{array}{c}- \\
+ \text { Mature }\end{array}$ & $\begin{array}{l}+ \text { Immature } \\
++ \text { Mature }\end{array}$ & ++ & $\begin{array}{l}+ \text { Immature } \\
++ \text { Mature }\end{array}$ & ++ & + & $?$ & - \\
\hline XCR1 & - & - & + & - & + & - & - & - \\
\hline CX3CR1 & $?$ & $\begin{array}{c}\text { + Blood } \\
\text { ? Lymphoid organs }\end{array}$ & - & $+1-$ & - & + & $?$ & $+1-$ \\
\hline BDCA1/CD1c & - & + & - & + & - & + & + & + \\
\hline Sirp- $\alpha / C D 172 a$ & - & + & - & + & - & + & + & + \\
\hline CD11b & - & $\begin{array}{c}\text { - Blood } \\
+ \text { Lymphoid organs }\end{array}$ & - & + & - & + & + & + \\
\hline MR/CD206 & - & - & - & + & - & + & ++ & - \\
\hline CD14 & - & - & - & - & - & + & + & - \\
\hline $\mathrm{F}_{c \varepsilon R \mathrm{R}}$ & - & + & - & $?$ & - & $?$ & + & - \\
\hline CD1a & - & - & - & $+1-$ & - & - & + & ++ \\
\hline CD64 & - & + & - & + & - & $?$ & + & $?$ \\
\hline Langerin/CD207 & - & - & - & $+1-$ & - & - & - & + \\
\hline EpCAM/CD326 & - & - & - & - & - & - & - & + \\
\hline E-cadherin & - & - & - & - & - & - & - & + \\
\hline
\end{tabular}

$+/-$, reported in some tissues. ?, not reported.

marrow suppression induced by preparative cytotoxic therapy (22). Patients carrying mutations in GATA2 or IRF8 lack all blood DC subsets, consistent with a common origin $(26,27)$. Several lines of evidence indicate that Flt3-L is required for the generation and/or maintenance of most DC subsets: injection of Flt3-L to human volunteers increases the number of blood DC subsets $(28,29)$; pDCs, CD1c ${ }^{+}$DCs, and $\mathrm{CD}_{141^{+}}$DCs equivalents can be derived in vitro by culturing $\mathrm{CD}_{3} 4^{+}$hematopoietic precursors with Flt3-L (30-32); levels of serum Flt3-L are elevated in patients affected by mutations in GATA2 or IRF8 $(26,27)$. The importance of other cytokines in DC differentiation or homeostasis in vivo is unclear. Recently, a committed DC progenitor (CDP) has been identified in bone marrow and cord blood, but was absent from adult blood and tonsils (33). In an in vitro culture model, these CDP give rise only to $\mathrm{pDC}$ and $\mathrm{CDCs}$, via an intermediate precursor restricted to $\mathrm{CD} 1 \mathrm{c}^{+} \mathrm{DCs}$ and $\mathrm{CD} 141^{+} \mathrm{DCs}(29,33)$. This pre-cDC is present in adult bone marrow, blood, and tonsils (29). Whether pre-cDC differentiate into cDCs in the blood or lymphoid organs and tissues remains to be addressed.

The ontogeny of migratory DCs also remains to be better characterized. Of note, patients affected with a mutation in GATA2 retain normal numbers of epidermal LC (27), showing that LC represent a distinct lineage from pDCs and cDCs. The observations that $\mathrm{LC}$ remained of donor origin 10 years after hand allograft and that they could proliferate in situ indicate that LC can self-renew in tissues (34). In addition, transcriptomic analysis shows that intestinal $\mathrm{CD}_{103}{ }^{-} \mathrm{CD} 172 \mathrm{a}^{+}$DCs (10) and inflammatory DCs (17) express monocyte gene signatures, suggesting that these DC subsets derive from monocytes rather than a common DC precursor.

Cross-species comparative transcriptomic analysis suggest that pDCs, CD1c ${ }^{+}$DCs, and CD141 ${ }^{+}$DCs represent distinct bona fide lineages, as homologies have been evidenced with the welldefined mouse DC subsets pDCs, CD11b ${ }^{+}$DCs, and $\mathrm{CD}^{+} \mathrm{DCs}$, respectively $(8,10,25)$. Regarding the molecular ontogeny, in vitro culture models indicate that the transcription factors E2-2 and Batf3 drive the differentiation of pDCs and CD141 ${ }^{+}$DCs, respectively (35-37). Of note, Batf3 silencing in humanized mice was not sufficient to inhibit CD141 ${ }^{+}$DC differentiation (37), which might be due to molecular compensation by related transcription factors as shown in Batf3-deficient mice (38). It has been proposed that $\mathrm{CD} 1 \mathrm{c}^{+}$DCs depend on IRF4 based on its preferential expression in $\mathrm{CD}_{1} \mathrm{c}^{+} \mathrm{DCs}(10,39)$, however this remains to be formally proven.

Another unresolved matter is the relationship of blood cDCs and their lymphoid organ and tissue counterparts. It has been suggested that blood $\mathrm{CD}_{1} \mathrm{c}^{+} \mathrm{DCs}$ and $\mathrm{CD} 141^{+}$DCs represent a precursor form of $\mathrm{cDC}$ subsets $(4,8,40)$, but a direct 
precursor-progeny relationship remains unclear. Consistent with the idea that they are not terminally differentiated, blood CD1c ${ }^{+}$ DCs and CD141 ${ }^{+}$DCs become competent for cross-presentation only after activation, whereas lymphoid organ DCs cross-present without the need for activation (41). Moreover, blood CD1c ${ }^{+}$DCs retain some plasticity as they can differentiate ex vivo into LC-like cells, while tonsil CD1c ${ }^{+}$DCs cannot $(42,43)$.

\section{IS THERE A FUNCTIONAL SPECIALIZATION OF HUMAN DC SUBSETS? \\ PATHOGEN RECOGNITION}

Among the variety of pathogen-recognition receptors, TLR expression by DC subsets (either mRNA or protein expression) has been the most studied. pDC express TLR1, TLR6, TLR7, TLR9, and TLR10, resident CD1c ${ }^{+}$DCs express TLR1, TLR2, TLR4, TLR5, TLR6, and TLR8, and resident CD141 ${ }^{+}$DCs express TLR1, TLR3, TLR6, TLR8, and TLR10 (3, 5, 44-46). Skin LC express TLR1, TLR2, TLR3, TLR6, TLR7 and vaginal mucosa LC express TLR8 in addition $(15,47,48)$, skin and vaginal mucosa CD1a ${ }^{+}$DCs express TLR6 and TLR8 while the expression of other TLR is less clear, and skin and vaginal mucosa CD14 ${ }^{+}$DCs express TLR1, TLR2, TLR4, TLR6, and TLR8 $(15,49)$. C-type lectin receptors are also important pathogen-recognition receptors, some of which have been reported to be differentially expressed by DC subsets by transcriptomic analysis $(17,49-52)$. Receptors whose differential expression among DC subsets has been confirmed at protein level include Clec9A on $\mathrm{CD} 141^{+} \mathrm{DCs}, \mathrm{BDCA} 2 / \mathrm{CD} 303$ on $\mathrm{pDC}$, ClecSF14/CD301 on CD1c ${ }^{+}$DCs, Langerin/CD207 on LC, and Clec10a and LOX-1 on CD14 ${ }^{+}$DCs $(5,19,49,53,54)$.

Differential expression of pathogen-recognition receptors can confer functional specialization to DC subsets for the response to pathogens $(46,55,56)$ or vaccines $(57)$.

Much work remains to be done to characterize the expression pattern of intracellular pathogen-recognition receptors in resident and migratory DC subsets. It has been reported so far that vaginal mucosa and skin LC, CD1a ${ }^{+}$DCs, and CD $14^{+}$DCs, all express MDA-5, while only CD14 ${ }^{+}$DCs express RIG-I $(15,49)$.

\section{CYTOKINE SECRETION}

Blood and lymphoid organ pDC have long been known to be the best producers of type I interferon (58-60). CD141 ${ }^{+}$DCs from blood and from humanized mice spleen have also been reported to be the most potent for type I interferon production after TLR3 stimulation $(5,61)$. More recently, blood and liver CD $141^{+}$DCs were shown to selectively secrete type III interferon after activation with TLR3 ligand or Hepatitis C virus $(56,62,63)$.

Because cytokine secretion by a given DC subset vary depending on the stimulus used (45), it can be difficult to determine bona fide specialization for cytokine secretion. Accumulating evidence indicates that blood CD1c ${ }^{+}$DCs are the best producers of IL-12p70, as shown by stimulation with TLR2, TLR3, and TLR8 ligands $(40,45,46)$. Whether $\mathrm{CD}^{+} \mathrm{c}^{+} \mathrm{DCs}$ from tissues are also specialized for IL-12p70 secretion needs to be confirmed. Indeed, no IL-12p70 secretion could be detected after stimulation of skin DC subsets (8) or intestinal CD1c ${ }^{+}$DCs (11) with several TLRligands. Intestinal and lung $\mathrm{CD}_{1} \mathrm{c}^{+} \mathrm{DCs}$ are also the best producers of IL-23 after TLR8 stimulation or Aspergillus fumigatus exposure, respectively $(11,39) . \mathrm{CD} \mathrm{c}^{+} \mathrm{DCs}$ from skin, intestine, and blood are also the most potent producers of IL-10 in response to several TLR-ligands $(8,11,64)$. Skin LC and CD1a ${ }^{+}$DCs have been reported to be better producers of IL-15 than skin CD14 ${ }^{+}$DCs $(53,65)$, but IL-15 secretion by other DC subsets has not been analyzed yet.

\section{CROSS-PRESENTATION AND CD8 T-CELL RESPONSES}

Numerous studies have shown that blood and lymphoid organ DC subsets can all cross-present efficiently various forms of antigen (66). Spleen, lymph node, and tonsil $\mathrm{CD}_{1} \mathrm{c}^{+}$and $\mathrm{CD} 141^{+}$ DC subsets are equally potent for cross-presenting soluble antigens, without the need for activation $(4,41,44)$. When stimulated with TLR-ligands that can activate both subsets, blood $\mathrm{CD}_{1}{ }^{+}$and $\mathrm{CD} 141^{+}$DCs also display similar efficiency for crosspresentation $(40,44,67)$. However, lymphoid organ and activated blood CD $141^{+}$DCs appear to be more efficient for the crosspresentation of dead cell-derived antigen $(5,41,68)$, which might be due to their selective expression of necrotic cell receptors such as Clec9A. Blood CD141 ${ }^{+}$DCs were also more efficient than $\mathrm{CD}_{1}{ }^{+} \mathrm{DCs}$ for cross-presentation of antigens delivered to late endocytic compartments via CD205 targeting, but were equally potent after antigen delivery to early endocytic compartments via CD40 (69).

Blood and lymphoid organ pDCs cross-present efficiently soluble $(41,44,67,70,71)$, viral (71-74), cell-associated antigen (67, $75)$, or antigen targeted to surface receptors such as CD40, DCIR, CD205, BDCA2/CD303, or CD32 $(67,69,76)$.

The ability of tissue DCs to cross-present is less well characterized. Skin CDla ${ }^{+}$DCs and LC have been shown to cross-present when purified from skin or skin-draining lymph nodes $(4,77)$, however, a subsequent study reported that skin $\mathrm{CD} 141^{+} \mathrm{Clec} 9 \mathrm{~A}^{+}$ DCs are the most efficient for cross-presentation compared to other skin DC subsets (8). Skin LC also cross-present antigen targeted through DCIR (76). Both CD1c ${ }^{+}$DCs and CD141 ${ }^{+}$ DCs from the lung of humanized mice can cross-present (9), but these results need to be confirmed with DCs directly purified from human lung. The cross-presentation capacity of migratory DCs from other tissues and of inflammatory DCs remains to be analyzed. In addition, which DC subsets cross-present in vivo in a physiological situation is a challenging question that is still unaddressed.

Skin LC and CDla ${ }^{+}$DCs induce the differentiation of cytotoxic T lymphocytes (CTL) more efficiently than skin CD14 ${ }^{+}$ DCs, through the secretion of IL-15 $(53,65)$. Activated LC also express higher levels of CD70, which promotes CTL differentiation $(55,77)$. Blood-activated CD1c ${ }^{+}$DCs induce higher expression of granzymes $\mathrm{B}$ and $\mathrm{K}$ by CTL than activated $\mathrm{CD} 141^{+} \mathrm{DCs}$, due to the selective secretion of IL-12p70 (40). Whether this specialization also applies to lymphoid organ and tissue $\mathrm{CD}^{+} \mathrm{c}^{+} \mathrm{DCs}$ remains to be confirmed.

\section{CD4 T CELLS RESPONSES}

The vast majority of studies have analyzed the ability of isolated DC subsets to stimulate and polarize allogeneic naive CD4 T cells. Blood, lymph node, or lung CD1c ${ }^{+}$DCs and CD $141^{+}$DCs are equally competent for Th1 polarization, either without activation 
$(4,78)$ or after exposure to influenza virus (78) or A. fumigatus (39). By contrast, blood and lung CD141 ${ }^{+}$DCs have been found to be more potent inducers of Th2 polarization compared to CD1c ${ }^{+}$ DCs, with or without activation, due to the selective expression of OX40-L (78). Lung CD1c ${ }^{+}$DCs exposed to A. fumigatus are more potent than $\mathrm{CD} 141^{+}$DCs for Th-17 polarization due to their secretion of IL-23 (39), however both intestinal CD1c ${ }^{+}$DCs and $\mathrm{CD} 141^{+}$DCs are equally able to induce Th-17 polarization (10). Blood pDC can induce Th1 polarization after activation with CD40-L, influenza virus, or Sendai virus $(60,79)$, but induce Th2 polarization through OX40-L after activation with IL3 (79). Whether these observations also apply to lymphoid organ pDC, and whether $\mathrm{pDC}$ can induce Th-17 polarization when adequately activated remains to be addressed.

Skin DC subsets have been proposed to be specialized for CD4 T-cell polarization, $\mathrm{LC}$, and $\mathrm{CD} 1 \mathrm{a}^{+} \mathrm{DCs}$ being especially potent for Th2 polarization while CD14 ${ }^{+}$DCs mainly induce T follicular helper (Tfh) cells (53). This specialization is conserved after skin DC migration to draining lymph nodes (4). The molecular mechanism underlying this functional specialization remains unclear. Moreover, vaginal mucosa LC and CD1a ${ }^{+}$DCs preferentially induce Th2 polarization, while vaginal mucosa $\mathrm{CD} 14^{+} \mathrm{DCs}$ are better inducers of Th1 (15). The ability of vaginal mucosa DCs to induce Tfh has not been analyzed. In addition, skin LC have

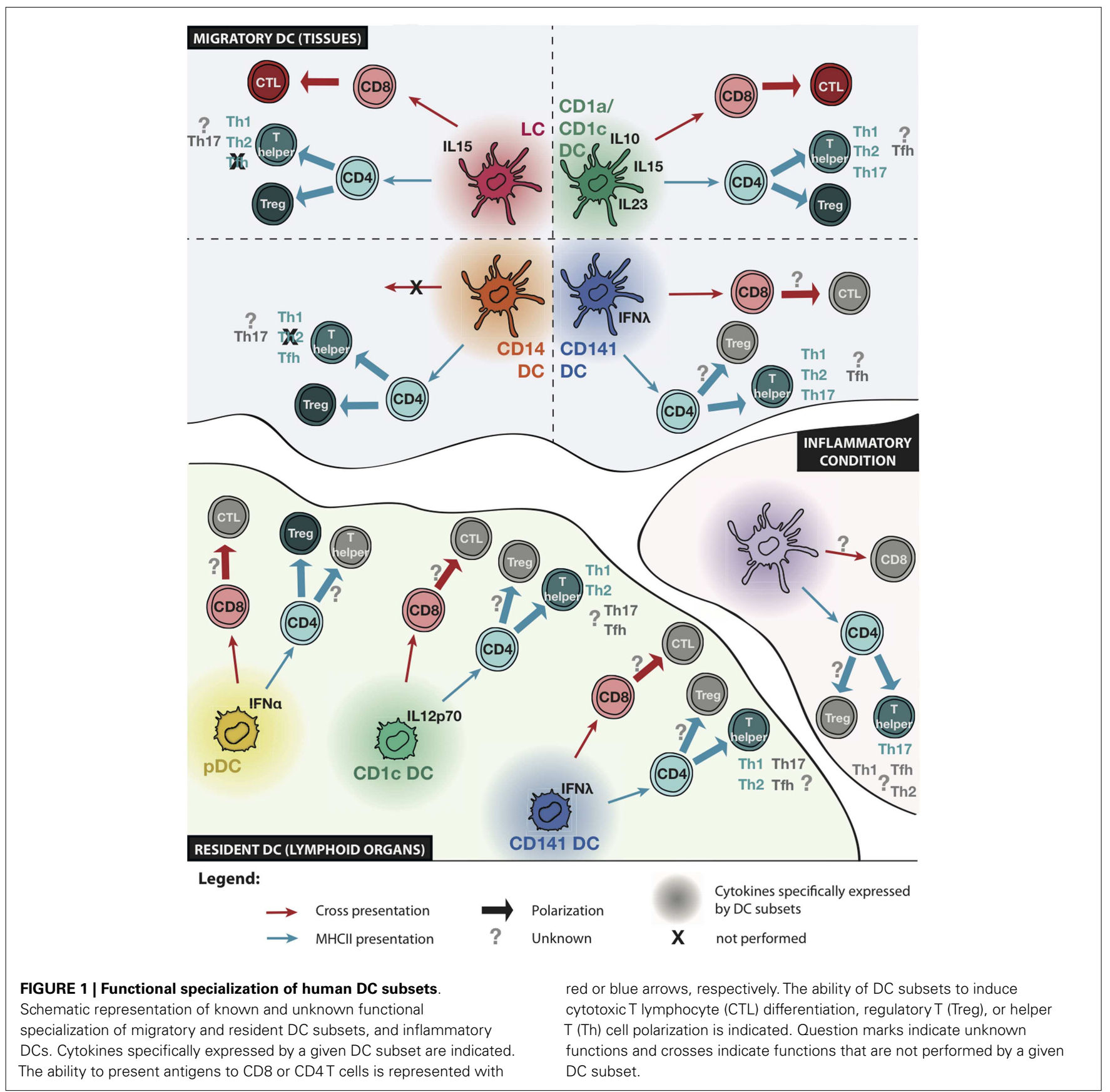


been found to be more potent than other skin DCs for the induction of IL22-secreting CD4 T cells $(80,81)$, while both vaginal mucosa LC and CD1a ${ }^{+}$DCs are equally competent (15).

Inflammatory DCs isolated from rheumatoid arthritis synovial fluid and from tumor ascites preferentially induce Th- 17 polarization through the secretion of Th-17 polarizing cytokines IL-6, IL-23, TGF $\beta$, and IL1- $\beta$ (17). Inflammatory DCs from tumor ascites also efficiently stimulate autologous effector CD4 T cells to secrete IL-17 (17). The CD4 T-cell responses induced by inflammatory DCs from other inflammatory environments remain to be investigated.

Finally, several DC subsets were shown to induce Treg: dermal $\mathrm{CD}_{14}{ }^{+}$DCs (20), intestinal CD1c ${ }^{+}$DCs and $\mathrm{CD} 103^{-} \mathrm{CD} 172 \mathrm{a}^{+}$ DCs (10), tonsil pDC activated with IL3 or TLR-ligands (82), and bacteria-exposed skin LC (83). In addition, liver DCs (7) and TLR4-activated oral mucosa DCs (84) were proposed to promote Treg induction through the secretion of IL-10, but whether one subset is more potent for Treg induction has not been analyzed. Blood Escherichia coli-activated CD1c ${ }^{+}$DCs have also been proposed to inhibit $\mathrm{CD} 4 \mathrm{~T}$-cell proliferation through IL-10 secretion (64). In addition, skin LC, but not dermal CD1 a ${ }^{+} \mathrm{DCs}$ and CD14 ${ }^{+}$ DCs, have been shown to stimulate the proliferation of autologous skin-resident memory Treg (85).

Collectively, these results suggest that some CD4 T-cell responses are the consequence of subset-intrinsic specialization, while others are more dependent on signals from the environment or on tissue imprinting (Figure 1). The clearer observations so far are the specialization of $\mathrm{CD} 141^{+}$DCs for Th2 polarization and of $\mathrm{CD} 14^{+}$DCs for Tfh polarization (both findings would need to be confirmed with DCs from other tissues), and of skin and vaginal mucosal LC and CD1a ${ }^{+}$DCs for Th2 and Th22 polarization. However, this specialization might be tissuedependent as lung $\mathrm{CD} 1 \mathrm{c}^{+} \mathrm{CD} 1 \mathrm{a}^{+} \mathrm{DCs}$ are not potent inducers of Th2 polarization.

\section{CONCLUSION}

Despite the technical challenges inherent to human DC work, significant progress has been made in the past few years in the characterization of human DC subsets. Important issues that will need further exploration include the ability of DC subsets to stimulate effector and memory $\mathrm{T}$ cells, the interplay between DC subsets, and the in vivo confirmation of functional specializations observed ex vivo. These could be achieved by the use of humanized mice models, the analysis of relevant pathological situations, or the study of patients with mutations in relevant genes.

This knowledge will be instrumental in the design of novel vaccines and DC-based immunotherapies.

\section{ACKNOWLEDGMENTS}

Our work is supported by INSERM, Institut Curie, Association pour la Recherche contre le Cancer.

\section{REFERENCES}

1. Merad M, Sathe P, Helft J, Miller J, Mortha A. The dendritic cell lineage: ontogeny and function of dendritic cells and their subsets in the steady state and the inflamed setting. Annu Rev Immunol (2013) 31:563-604. doi:10.1146/annurevimmunol-020711-074950
2. Ziegler-Heitbrock L, Ancuta P, Crowe S, Dalod M, Grau V, Hart DN, et al. Nomenclature of monocytes and dendritic cells in blood. Blood (2010) 116(16):e74-80. doi:10.1182/blood-2010-02-258558

3. Lindstedt M, Lundberg K, Borrebaeck CA. Gene family clustering identifies functionally associated subsets of human in vivo blood and tonsillar dendritic cells. J Immunol (2005) 175(8):4839-46. doi:10.4049/jimmunol.175. 8.4839

4. Segura E, Valladeau-Guilemond J, Donnadieu MH, Sastre-Garau X, Soumelis V, Amigorena S. Characterization of resident and migratory dendritic cells in human lymph nodes. J Exp Med (2012) 209(4):653-60. doi:10.1084/jem. 20111457

5. Jongbloed SL, Kassianos AJ, McDonald KJ, Clark GJ, Ju X, Angel CE, et al. Human CD141+ (BDCA-3) + dendritic cells (DCs) represent a unique myeloid DC subset that cross-presents necrotic cell antigens. J Exp Med (2010) 207(6):1247-60. doi:10.1084/jem.20092140

6. Poulin LF, Salio M, Griessinger E, Anjos-Afonso F, Craciun L, Chen JL, et al. Characterization of human DNGR-1+ BDCA3+ leukocytes as putative equivalents of mouse CD8alpha+ dendritic cells. J Exp Med (2010) 207(6):1261-71. doi:10.1084/jem.20092618

7. Bamboat ZM, Stableford JA, Plitas G, Burt BM, Nguyen HM, Welles AP, et al. Human liver dendritic cells promote $\mathrm{T}$ cell hyporesponsiveness. I Immunol (2009) 182(4):1901-11. doi:10.4049/jimmunol.0803404

8. Haniffa M, Shin A, Bigley V, McGovern N, Teo P, See P, et al. Human tissues contain CD141(hi) cross-presenting dendritic cells with functional homology to mouse CD103(+) nonlymphoid dendritic cells. Immunity (2012) 37(1):60-73. doi:10.1016/j.immuni.2012.04.012

9. Yu CI, Becker C, Wang Y, Marches F, Helft J, Leboeuf M, et al. Human CD1c(+) dendritic cells drive the differentiation of CD103(+) CD8(+) mucosal effector T cells via the cytokine TGF-beta. Immunity (2013) 38(4):818-30. doi:10.1016/j.immuni.2013.03.004

10. Watchmaker PB, Lahl K, Lee M, Baumjohann D, Morton J, Kim SJ, et al. Comparative transcriptional and functional profiling defines conserved programs of intestinal DC differentiation in humans and mice. Nat Immunol (2014) 15(1):98-108. doi:10.1038/ni.2768

11. Dillon SM, Rogers LM, Howe R, Hostetler LA, Buhrman J, McCarter MD, et al. Human intestinal lamina propria CD1c+ dendritic cells display an activated phenotype at steady state and produce IL-23 in response to TLR7/8 stimulation. J Immunol (2010) 184(12):6612-21. doi:10.4049/jimmunol.1000041

12. Demedts IK, Brusselle GG, Vermaelen KY, Pauwels RA. Identification and characterization of human pulmonary dendritic cells. Am J Respir Cell Mol Biol (2005) 32(3):177-84. doi:10.1165/rcmb.2004-02790C

13. Morandi B, Bonaccorsi I, Mesiti M, Conte R, Carrega P, Costa G, et al. Characterization of human afferent lymph dendritic cells from seroma fluids. J Immunol (2013) 191(9):4858-66. doi:10.4049/jimmunol.1300760

14. Angel CE, Chen CJ, Horlacher OC, Winkler S, John T, Browning J, et al. Distinctive localization of antigen-presenting cells in human lymph nodes. Blood (2009) 113(6):1257-67. doi:10.1182/blood-2008-06-165266

15. Duluc D, Gannevat J, Anguiano E, Zurawski S, Carley M, Boreham M, et al. Functional diversity of human vaginal APC subsets in directing T-cell responses. Mucosal Immunol (2013) 6(3):626-38. doi:10.1038/mi.2012.104

16. Nestle FO, Zheng XG, Thompson CB, Turka LA, Nickoloff BJ. Characterization of dermal dendritic cells obtained from normal human skin reveals phenotypic and functionally distinctive subsets. J Immunol (1993) 151(11):6535-45.

17. Segura E, Touzot M, Bohineust A, Cappuccio A, Chiocchia G, Hosmalin A, et al. Human inflammatory dendritic cells induce Th17 cell differentiation. Immunity (2013) 38(2):336-48. doi:10.1016/j.immuni.2012.10.018

18. Guttman-Yassky E, Lowes MA, Fuentes-Duculan J, Whynot J, Novitskaya I, Cardinale I, et al. Major differences in inflammatory dendritic cells and their products distinguish atopic dermatitis from psoriasis. J Allergy Clin Immunol (2007) 119(5):1210-7. doi:10.1016/j.jaci.2007.03.006

19. Dzionek A, Fuchs A, Schmidt P, Cremer S, Zysk M, Miltenyi S, et al. BDCA2, BDCA-3, and BDCA-4: three markers for distinct subsets of dendritic cells in human peripheral blood. J Immunol (2000) 165(11):6037-46. doi:10.4049/ jimmunol.165.11.6037

20. Chu CC, Ali N, Karagiannis P, Di Meglio P, Skowera A, Napolitano L, et al. Resident CD141 (BDCA3)+ dendritic cells in human skin produce IL-10 and induce regulatory $\mathrm{T}$ cells that suppress skin inflammation. J Exp Med (2012) 209(5):935-45. doi:10.1084/jem.20112583 
21. Schreibelt G, Klinkenberg LJ, Cruz LJ, Tacken PJ, Tel J, Kreutz M, et al. The C-type lectin receptor CLEC9A mediates antigen uptake and (cross-)presentation by human blood BDCA3+ myeloid dendritic cells. Blood (2012) 119(10):2284-92. doi:10.1182/blood-2011-08-373944

22. McGovern N, Schlitzer A, Gunawan M, Jardine L, Shin A, Poyner E, et al. Human dermal CD14(+) cells are a transient population of monocytederived macrophages. Immunity (2014) 41(3):465-77. doi:10.1016/j.immuni. 2014.08.006

23. Haniffa M, Ginhoux F, Wang XN, Bigley V, Abel M, Dimmick I, et al. Differential rates of replacement of human dermal dendritic cells and macrophages during hematopoietic stem cell transplantation. J Exp Med (2009) 206(2):371-85. doi:10.1084/jem.20081633

24. Cros J, Cagnard N, Woollard K, Patey N, Zhang SY, Senechal B, et al. Human CD14dim monocytes patrol and sense nucleic acids and viruses via TLR7 and TLR8 receptors. Immunity (2010) 33(3):375-86. doi:10.1016/j.immuni.2010. 08.012

25. Robbins SH, Walzer T, Dembele D, Thibault C, Defays A, Bessou G, et al. Novel insights into the relationships between dendritic cell subsets in human and mouse revealed by genome-wide expression profiling. Genome Biol (2008) 9(1):R17. doi:10.1186/gb-2008-9-1-r17

26. Hambleton S, Salem S, Bustamante J, Bigley V, Boisson-Dupuis S, Azevedo J, et al. IRF8 mutations and human dendritic-cell immunodeficiency. N Engl J Med (2011) 365(2):127-38. doi:10.1056/NEJMoa1100066

27. Bigley V, Haniffa M, Doulatov S, Wang XN, Dickinson R, McGovern N, et al. The human syndrome of dendritic cell, monocyte, B and NK lymphoid deficiency. J Exp Med (2011) 208(2):227-34. doi:10.1084/jem.20101459

28. Pulendran B, Banchereau J, Burkeholder S, Kraus E, Guinet E, Chalouni $\mathrm{C}$, et al. Flt3-ligand and granulocyte colony-stimulating factor mobilize distinct human dendritic cell subsets in vivo. J Immunol (2000) 165(1):566-72. doi:10.4049/jimmunol.165.1.566

29. Breton G, Lee J, Zhou YJ, Schreiber JJ, Keler T, Puhr S, et al. Circulating precursors of human CD1c+ and CD141+ dendritic cells. J Exp Med (2015) 212(3):401-13. doi:10.1084/jem.20141441

30. Chen W, Antonenko S, Sederstrom JM, Liang X, Chan AS, Kanzler H, et al. Thrombopoietin cooperates with FLT3-ligand in the generation of plasmacytoid dendritic cell precursors from human hematopoietic progenitors. Blood (2004) 103(7):2547-53. doi:10.1182/blood-2003-09-3058

31. Blom B, Ho S, Antonenko S, Liu YJ. Generation of interferon alpha-producing predendritic cell (Pre-DC)2 from human CD34(+) hematopoietic stem cells. J Exp Med (2000) 192(12):1785-96. doi:10.1084/jem.192.12.1785

32. Proietto AI, Mittag D, Roberts AW, Sprigg N, Wu L. The equivalents of human blood and spleen dendritic cell subtypes can be generated in vitro from human $\mathrm{CD} 34(+)$ stem cells in the presence of fms-like tyrosine kinase 3 ligand and thrombopoietin. Cell Mol Immunol (2012) 9(6):446-54. doi:10.1038/ cmi. 2012.48

33. Lee J, Breton G, Oliveira TY, Zhou YJ, Aljoufi A, Puhr S, et al. Restricted dendritic cell and monocyte progenitors in human cord blood and bone marrow. J Exp Med (2015) 212(3):385-99. doi:10.1084/jem.20141442

34. Kanitakis J, Morelon E, Petruzzo P, Badet L, Dubernard JM. Self-renewal capacity of human epidermal Langerhans cells: observations made on a composite tissue allograft. Exp Dermatol (2011) 20(2):145-6. doi:10.1111/j.1600-0625.2010. 01146.x

35. Cisse B, Caton ML, Lehner M, Maeda T, Scheu S, Locksley R, et al. Transcription factor E2-2 is an essential and specific regulator of plasmacytoid dendritic cell development. Cell (2008) 135(1):37-48. doi:10.1016/j.cell.2008.09.016

36. Nagasawa M, Schmidlin H, Hazekamp MG, Schotte R, Blom B. Development of human plasmacytoid dendritic cells depends on the combined action of the basic helix-loop-helix factor E2-2 and the Ets factor Spi-B. Eur J Immunol (2008) 38(9):2389-400. doi:10.1002/eji.200838470

37. Poulin LF, Reyal Y, Uronen-Hansson H, Schraml B, Sancho D, Murphy KM, et al. DNGR-1 is a specific and universal marker of mouse and human Batf3dependent dendritic cells in lymphoid and non-lymphoid tissues. Blood (2012) 119(25):6052-62. doi:10.1182/blood-2012-01-406967

38. Tussiwand R, Lee WL, Murphy TL, Mashayekhi M, Kc W, Albring JC, et al. Compensatory dendritic cell development mediated by BATF-IRF interactions. Nature (2012) 490(7421):502-7. doi:10.1038/nature11531

39. Schlitzer A, McGovern N, Teo P, Zelante T, Atarashi K, Low D, et al. IRF4 transcription factor-dependent $\mathrm{CD} 1 \mathrm{lb}+$ dendritic cells in human and mouse control mucosal IL-17 cytokine responses. Immunity (2013) 38(5):970-83. doi:10.1016/j.immuni.2013.04.011

40. Nizzoli G, Krietsch J, Weick A, Steinfelder S, Facciotti F, Gruarin P, et al. Human CD1c+ dendritic cells secrete high levels of IL-12 and potently prime cytotoxic T cell responses. Blood (2013) 122(6):932-42. doi:10.1182/blood-201304-495424

41. Segura E, Durand M, Amigorena S. Similar antigen cross-presentation capacity and phagocytic functions in all freshly isolated human lymphoid organ-resident dendritic cells. J Exp Med (2013) 210(5):1035-47. doi:10.1084/jem.20121103

42. Martinez-Cingolani C, Grandclaudon M, Jeanmougin M, Jouve M, Zollinger R, Soumelis V. Human blood BDCA-1 dendritic cells differentiate into Langerhanslike cells with thymic stromal lymphopoietin and TGF-beta. Blood (2014) 124(15):2411-20. doi:10.1182/blood-2014-04-568311

43. Milne P, Bigley V, Gunawan M, Haniffa M, Collin M. CD1c+ blood dendritic cells have Langerhans cell potential. Blood (2014) 125(3):470-3. doi:10.1182/ blood-2014-08-593582

44. Mittag D, Proietto AI, Loudovaris T, Mannering SI, Vremec D, Shortman K, et al. Human dendritic cell subsets from spleen and blood are similar in phenotype and function but modified by donor health status. J Immunol (2011) 186(11):6207-17. doi:10.4049/jimmunol.1002632

45. Hemont C, Neel A, Heslan M, Braudeau C, Josien R. Human blood mDC subsets exhibit distinct TLR repertoire and responsiveness. J Leukoc Biol (2013) 93(4):599-609. doi:10.1189/jlb.0912452

46. Jin JO, Zhang W, Du JY, Yu Q. BDCA1-positive dendritic cells (DCs) represent a unique human myeloid DC subset that induces innate and adaptive immune responses to Staphylococcus aureus infection. Infect Immun (2014) 82(11):4466-76. doi:10.1128/IAI.01851-14

47. van der Aar AM, Sylva-Steenland RM, Bos JD, Kapsenberg ML, de Jong EC, Teunissen MB. Loss of TLR2, TLR4, and TLR5 on Langerhans cells abolishes bacterial recognition. J Immunol (2007) 178(4):1986-90. doi:10.4049/jimmunol.178. 4.1986

48. Flacher V, Bouschbacher M, Verronese E, Massacrier C, Sisirak V, BerthierVergnes $\mathrm{O}$, et al. Human Langerhans cells express a specific TLR profile and differentially respond to viruses and Gram-positive bacteria. J Immunol (2006) 177(11):7959-67. doi:10.4049/jimmunol.177.11.7959

49. Duluc D, Banchereau R, Gannevat J, Thompson-Snipes L, Blanck JP, Zurawski $\mathrm{S}$, et al. Transcriptional fingerprints of antigen-presenting cell subsets in the human vaginal mucosa and skin reflect tissue-specific immune microenvironments. Genome Med (2014) 6(11):98. doi:10.1186/s13073-014-0098-y

50. Santegoets SJ, Gibbs S, Kroeze K, van de Ven R, Scheper RJ, Borrebaeck CA, et al. Transcriptional profiling of human skin-resident Langerhans cells and CDla+ dermal dendritic cells: differential activation states suggest distinct functions. J Leukoc Biol (2008) 84(1):143-51. doi:10.1189/jlb.1107750

51. Lundberg K, Albrekt AS, Nelissen I, Santegoets S, de Gruijl TD, Gibbs S, et al. Transcriptional profiling of human dendritic cell populations and models unique profiles of in vitro dendritic cells and implications on functionality and applicability. PLoS One (2013) 8(1):e52875. doi:10.1371/journal.pone.0052875

52. Harman AN, Bye CR, Nasr N, Sandgren KJ, Kim M, Mercier SK, et al. Identification of lineage relationships and novel markers of blood and skin human dendritic cells. J Immunol (2013) 190(1):66-79. doi:10.4049/jimmunol.1200779

53. Klechevsky E, Morita R, Liu M, Cao Y, Coquery S, Thompson-Snipes L, et al. Functional specializations of human epidermal Langerhans cells and CD14+ dermal dendritic cells. Immunity (2008) 29(3):497-510. doi:10.1016/j.immuni. 2008.07.013

54. Lundberg K, Rydnert F, Greiff L, Lindstedt M. Human blood dendritic cell subsets exhibit discriminative pattern recognition receptor profiles. Immunology (2014) 142(2):279-88. doi:10.1111/imm.12252

55. van der Aar AM, de Groot R, Sanchez-Hernandez M, Taanman EW, van Lier RA, Teunissen MB, et al. Cutting edge: virus selectively primes human Langerhans cells for CD70 expression promoting CD8+ T cell responses. J Immunol (2011) 187(7):3488-92. doi:10.4049/jimmunol.1101105

56. Zhang S, Kodys K, Li K, Szabo G. Human type 2 myeloid dendritic cells produce interferon-lambda and amplify interferon-alpha in response to hepatitis $\mathrm{C}$ virus infection. Gastroenterology (2013) 144(2):414-25.e7. doi:10.1053/j.gastro.2012. 10.034

57. Banchereau R, Baldwin N, Cepika AM, Athale S, Xue Y, Yu CI, et al. Transcriptional specialization of human dendritic cell subsets in response to microbial vaccines. Nat Commun (2014) 5:5283. doi:10.1038/ncomms6283 
58. Cella M, Jarrossay D, Facchetti F, Alebardi O, Nakajima H, Lanzavecchia A, et al. Plasmacytoid monocytes migrate to inflamed lymph nodes and produce large amounts of type I interferon. Nat Med (1999) 5(8):919-23. doi:10. $1038 / 11360$

59. Siegal FP, Kadowaki N, Shodell M, Fitzgerald-Bocarsly PA, Shah K, Ho S, et al. The nature of the principal type 1 interferon-producing cells in human blood. Science (1999) 284(5421):1835-7. doi:10.1126/science.284.5421.1835

60. Cella M, Facchetti F, Lanzavecchia A, Colonna M. Plasmacytoid dendritic cells activated by influenza virus and CD40L drive a potent TH1 polarization. Nat Immunol (2000) 1(4):305-10. doi:10.1038/79747

61. Meixlsperger S, Leung CS, Ramer PC, Pack M, Vanoaica LD, Breton G, et al. $\mathrm{CD} 141+$ dendritic cells produce prominent amounts of IFN-alpha after dsRNA recognition and can be targeted via DEC-205 in humanized mice. Blood (2013) 121(25):5034-44. doi:10.1182/blood-2012-12-473413

62. Lauterbach H, Bathke B, Gilles S, Traidl-Hoffmann C, Luber CA, Fejer G, et al. Mouse CD8alpha+ DCs and human BDCA3+ DCs are major producers of IFN-lambda in response to poly IC. J Exp Med (2010) 207(12):2703-17. doi:10.1084/jem.20092720

63. Yoshio S, Kanto T, Kuroda S, Matsubara T, Higashitani K, Kakita N, et al. Human blood dendritic cell antigen $3(\mathrm{BDCA} 3)(+)$ dendritic cells are a potent producer of interferon-lambda in response to hepatitis C virus. Hepatology (2013) 57(5):1705-15. doi:10.1002/hep.26182

64. Kassianos AJ, Hardy MY, Ju X, Vijayan D, Ding Y, Vulink AJ, et al. Human CD1c (BDCA-1)+ myeloid dendritic cells secrete IL-10 and display an immunoregulatory phenotype and function in response to Escherichia coli. Eur J Immunol (2012) 42(6):1512-22. doi:10.1002/eji.201142098

65. Banchereau J, Thompson-Snipes L, Zurawski S, Blanck JP, Cao Y, Clayton S, et al. The differential production of cytokines by human Langerhans cells and dermal CD14(+) DCs controls CTL priming. Blood (2012) 119(24):5742-9. doi:10.1182/blood-2011-08-371245

66. Segura E, Amigorena S. Cross-presentation by human dendritic cell subsets. Immunol Lett (2014) 158(1-2):73-8. doi:10.1016/j.imlet.2013.12.001

67. Tel J, Schreibelt G, Sittig SP, Mathan TS, Buschow SI, Cruz LJ, et al. Human plasmacytoid dendritic cells efficiently cross-present exogenous Ags to CD8+ T cells despite lower Ag uptake than myeloid dendritic cell subsets. Blood (2013) 121(3):459-67. doi:10.1182/blood-2012-06-435644

68. Crozat K, Guiton R, Contreras V, Feuillet V, Dutertre CA, Ventre E, et al. The XC chemokine receptor 1 is a conserved selective marker of mammalian cells homologous to mouse CD8alpha+ dendritic cells. J Exp Med (2010) 207(6):1283-92. doi:10.1084/jem.20100223

69. Cohn L, Chatterjee B, Esselborn F, Smed-Sorensen A, Nakamura N, Chalouni $\mathrm{C}$, et al. Antigen delivery to early endosomes eliminates the superiority of human blood BDCA3+ dendritic cells at cross presentation. J Exp Med (2013) 210(5):1049-63. doi:10.1084/jem.20121251

70. Aspord C, Leloup C, Reche S, Plumas J. pDCs efficiently process synthetic long peptides to induce functional virus- and tumour-specific T-cell responses. Eur J Immunol (2014) 44(10):2880-92. doi:10.1002/eji.201444588

71. Hoeffel G, Ripoche AC, Matheoud D, Nascimbeni M, Escriou N, Lebon P, et al. Antigen crosspresentation by human plasmacytoid dendritic cells. Immunity (2007) 27(3):481-92. doi:10.1016/j.immuni.2007.07.021

72. Di Pucchio T, Chatterjee B, Smed-Sorensen A, Clayton S, Palazzo A, Montes $\mathrm{M}$, et al. Direct proteasome-independent cross-presentation of viral antigen by plasmacytoid dendritic cells on major histocompatibility complex class I. Nat Immunol (2008) 9(5):551-7. doi:10.1038/ni.1602

73. Lui G, Manches O, Angel J, Molens JP, Chaperot L, Plumas J. Plasmacytoid dendritic cells capture and cross-present viral antigens from influenza-virus exposed cells. PLoS One (2009) 4(9):e7111. doi:10.1371/journal.pone.0007111

74. Zhang X, Casartelli N, Lemoine S, Mozeleski B, Azria E, Le Ray C, et al. Plasmacytoid dendritic cells engagement by influenza vaccine as a surrogate strategy for driving T-helper type 1 responses in human neonatal settings. J Infect Dis (2014) 210(3):424-34. doi:10.1093/infdis/jiu103

75. Guillerme JB, Boisgerault N, Roulois D, Menager J, Combredet C, Tangy F, et al. Measles virus vaccine-infected tumor cells induce tumor antigen crosspresentation by human plasmacytoid dendritic cells. Clin Cancer Res (2013) 19(5):1147-58. doi:10.1158/1078-0432.CCR-12-2733

76. Klechevsky E, Flamar AL, Cao Y, Blanck JP, Liu M, O’Bar A, et al. Cross-priming CD8+ T cells by targeting antigens to human dendritic cells through DCIR. Blood (2010) 116(10):1685-97. doi:10.1182/blood-2010-01-264960

77. Polak ME, Newell L, Taraban VY, Pickard C, Healy E, Friedmann PS, et al. CD70-CD27 interaction augments CD8+ T-cell activation by human epidermal Langerhans cells. J Invest Dermatol (2012) 132(6):1636-44. doi:10.1038/jid. 2012.26

78. Yu CI, Becker C, Metang P, Marches F, Wang Y, Toshiyuki H, et al. Human CD141+ dendritic cells induce CD4+ T cells to produce type 2 cytokines. J Immunol (2014) 193(9):4335-43. doi:10.4049/jimmunol.1401159

79. Ito T, Amakawa R, Inaba M, Hori T, Ota M, Nakamura K, et al. Plasmacytoid dendritic cells regulate Th cell responses through OX40 ligand and type I IFNs. J Immunol (2004) 172(7):4253-9. doi:10.4049/jimmunol.172.7.4253

80. Fujita H, Nograles KE, Kikuchi T, Gonzalez J, Carucci JA, Krueger JG. Human Langerhans cells induce distinct IL-22-producing CD4+ T cells lacking IL-17 production. Proc Natl Acad Sci U S A (2009) 106(51):21795-800. doi:10.1073/ pnas.0911472106

81. Penel-Sotirakis K, Simonazzi E, Peguet-Navarro J, Rozieres A. Differential capacity of human skin dendritic cells to polarize CD4+ T cells into IL-17, IL-2 and IL-22 producing cells. PLoS One (2012) 7(11):e45680. doi:10.1371/journal. pone. 0045680

82. Palomares O, Ruckert B, Jartti T, Kucuksezer UC, Puhakka T, Gomez E, et al. Induction and maintenance of allergen-specific FOXP3+ Treg cells in human tonsils as potential first-line organs of oral tolerance. J Allergy Clin Immunol (2012) 129(2):510-20, 520.e1-9. doi:10.1016/j.jaci.2011.09.031

83. van der Aar AM, Picavet DI, Muller FJ, de Boer L, van Capel TM, Zaat SA, et al. Langerhans cells favor skin flora tolerance through limited presentation of bacterial antigens and induction of regulatory T cells. J Invest Dermatol (2013) 133(5):1240-9. doi:10.1038/jid.2012.500

84. Allam JP, Peng WM, Appel T, Wenghoefer M, Niederhagen B, Bieber T, et al. Tolllike receptor 4 ligation enforces tolerogenic properties of oral mucosal Langerhans cells. J Allergy Clin Immunol (2008) 121(2):368-74.e1. doi:10.1016/j.jaci. 2007.09.045

85. Seneschal J, Clark RA, Gehad A, Baecher-Allan CM, Kupper TS. Human epidermal Langerhans cells maintain immune homeostasis in skin by activating skin resident regulatory T cells. Immunity (2012) 36(5):873-84. doi:10.1016/j. immuni.2012.03.018

Conflict of Interest Statement: The authors declare that the research was conducted in the absence of any commercial or financial relationships that could be construed as a potential conflict of interest.

Received: 14 January 2015; accepted: 09 March 2015; published online: 23 March 2015. Citation: Durand Mand Segura E (2015) The known unknowns of the human dendritic cell network. Front. Immunol. 6:129. doi: 10.3389/fimmu.2015.00129

This article was submitted to Antigen Presenting Cell Biology, a section of the journal Frontiers in Immunology.

Copyright (c) 2015 Durand and Segura. This is an open-access article distributed under the terms of the Creative Commons Attribution License (CC BY). The use, distribution or reproduction in other forums is permitted, provided the original author (s) or licensor are credited and that the original publication in this journal is cited, in accordance with accepted academic practice. No use, distribution or reproduction is permitted which does not comply with these terms. 